\title{
PERAN PEMERINTAH TERHADAP PROGRAM PEMBERDAYAAN KOMUNITAS ADAT TERPENCIL SUKU ANAK DALAM (SAD) DI PROVINSI JAMBI TAHUN 2018
}

\section{The Role of Government toward KAT SAD Empowerment Program in Jambi Province in 2018}

\author{
Febi Rizka Eliza1, M. Ridwan² dan Dwi Noerjoedianto ${ }^{2}$ \\ ${ }^{1}$ Mahasiswa Program Studi Ilmu Kesehatan Masyarakat FKM UNJA \\ ${ }^{2}$ Dosen Program Studi Ilmu Kesehatan Masyarakat FKM UNJA
}

\begin{abstract}
Abstrak
Pemerintah memiliki peranan penting dalam keberhasilan program pemberdayaan KAT SAD di bidang kesehatan dan sosial. Program pemberdayaan yang dilakukan memiliki keterikatan erat dengan pembangunan berkelanjutan (sustainable development). Tujuan penelitian ini adalah untuk mengetahui peran pemerintah terhadap program pemberdayaan KAT SAD di bidang kesehatan dan sosial serta pengaruhnya dalam pembangunan berkelanjutan (sustainable development). Penelitian ini menggunakan pendekatan kualitatif studi kasus. Data dikumpulkan menggunakan metode triangulasi dan dianalisis dengan menggunakan metode Miles and Hubermen. Hasil penelitian ini menunjukkan bahwa peran serta kebijakan pemerintah dalam pemberdayaan KAT SAD di bidang kesehatan dapat dilihat dengan diterapkannya program pelayanan kesehatan langsung yang diterima KAT SAD seperti Puskesmas keliling, pengobatan gratis dan akses layanan kesehatan ke RSUD Raden Mattaher. Sedangkan dalam bidang sosial, Pemerintah telah berupaya menyiapkan pemukiman dan berbagai bentuk bantuan sosial yang dapat dikembangkan. Namun hal ini belum terealisasikan dengan baik karena KAT SAD belum mampu memberdayakan dirinya maupun keluarganya secara mandiri. Keberlanjutan program pemberdayaan KAT SAD yang telah dilaksanakan belum menunjukkan hasil yang optimal. Hal ini dibuktikan dengan kegiatan yang dilaksanakan tidak berkelanjutan dan belum menunjukkan hasil sesuai dengan harapan dari Pemerintah Provinsi dan Kabupaten Batang Hari, yakni kesetaraan kondisi sosial dan status kesehatan yang mumpuni.
\end{abstract}

Kata Kunci: Kebijakan pemerintah, Pemberdayaan KAT SAD, Pembangunan berkelanjutan

\begin{abstract}
The government has an important role in the success of the KAT SAD empowerment program in the health and social field. The programs have a close attachment to sustainable development. The purpose of this research is to know the role of government policy toward KAT SAD empowerment program in health and social field and its influence in sustainable development. This research use qualitative approach of case study. Data were collected using triangulation method and analyzed with Miles and Hubermen method. The results of the role of government policy in health empowerment can be seen by the implementation of direct health service programs received by KAT SAD such as mobile health center, free medical treatment and access to Raden Mattaher Hospital. Meanwhile, In the social field, The government has tried to prepare settlement areas and various forms of social assistance that can be developed. But this has not been realized properly because KAT SAD has not been able to empower themselves and their families independently. The sustainability of the KAT SAD empowerment program that has been implemented has not shown optimal results. This is evidenced by the activities carried out are not sustainable and have not shown results in accordance with the expectation of the Provincial Government and Batang Hari District, which are the equality of social condition and health status that qualify.
\end{abstract}

Keywords : Government policy, KAT SAD Empowerment, Sustainable development

Korespondensi: Febi Rizka Eliza

Email: febi.rizka@gmail.com 


\section{PENDAHULUAN}

Komunitas dapat didefinisikan sebagai suatu kesatuan hidup manusia yang menempati suatu wilayah yang nyata dan berinteraksi menurut suatu sistem adat istiadat dan yang terikat oleh suatu rasa identitas komunitas. Komunitas adat terpencil merupakan kelompok sosial budaya yang bersifat lokal, relatif kecil, tertutup, tertinggal, homogen, terpencar, berpindah-pindah, kehidupannya masih berpegang teguh pada adat istiadat, kondisi geografis yang sulit dijangkau, penghidupan tergantung sumberdaya alam setempat, teknologi yang digunakan masih sederhana dan ekonomi subsisten serta terbatasnya akses pelayanan sosial ${ }^{1}$.

Pada tahun 2017, Jumlah Komunitas Adat Terpencil SAD di Provinsi Jambi sebanyak 3.147 KK yang tersebar di 8 Kabupaten, 18 Kecamatan, 20 Desa dan 28 lokasi. Batang Hari (454 KK), Muaro Jambi (0 KK), Sarolangun (249 KK), Tebo (415 KK), Bungo (128 KK), Merangin (165 KK), Tanjab Barat (100 KK) dan Tanjab Timur $(76 \mathrm{KK})^{2}$.

Komunitas Adat Terpencil SAD telah mendapat perhatian dari Pemerintah melalui kegiatan pemberdayaan. Tujuan utama pemberdayaan adalah memperkuat kekuasaan masyarakat, khususnya kelompok lemah yang memiliki ketidakberdayaan, baik karena kondisi internal maupun karena kondisi eksternal. Memberdayakan masyarakat adalah upaya untuk meningkatkan harkat dan martabat lapisan masyarakat yang dalam kondisi sekarang tidak mampu untuk melepaskan diri dari perangkap kemiskinan dan keterbelakangan ${ }^{3}$.

Pemerintah Provinsi Jambi telah berupaya dalam memberdayakan Komunitas Adat Terpencil SAD, Hal ini dapat dilihat berdasarkan jumlah Komunitas Adat Terpencil SAD di Provinsi Jambi yang telah diberdayakan sebanyak 3.229 KK yang tersebar di 8 Kabupaten. Batang Hari (763 KK), Muaro Jambi (427 KK), Sarolangun (753 KK), Tebo
(464 KK), Bungo (275 KK), Merangin (297 KK), Tanjab Barat (100 KK) dan Tanjab Timur $(150 \mathrm{KK})^{2}$.

Penelitian ini mengkaji hal-hal yang lebih mendalam terkait: (1) pelaksanaan studi yang melibatkan aktor-aktor pemberdayaan Komunitas Adat Terpencil SAD, sehingga informasi yang didapatkan mampu menggambarkan kondisi real Komunitas Adat Terpencil SAD saat ini; (2) tidak saja dalam pelaksanaan studi, lebih dari itu penelitian ini mencoba bergerak kearah yang lebih mendalam dengan memahami peran pemerintah terhadap program pemberdayaan yang telah dilakukan, khususnya pemberdayaan dalam bidang kesehatan dan sosial.

\section{METODE}

Penelitian ini merupakan penelitian kualitatif dengan pendekatan studi kasus. Studi kasus merupakan jenis penelitian kualitatif yang melakukan eksplorasi secara mendalam terhadap program, kejadian, proses dan aktivitas terhadap satu atau lebih orang ${ }^{4}$. Penelitian ini dilakukan di Provinsi Jambi, yaitu Kota Jambi dan Kabupaten Batang Hari pada bulan April tahun 2018. Metode pengumpulan data yang dilakukan dalam penelitian ini adalah wawancara mendalam (in-depth interview) dan telaah dokumen, selanutnya dianalisis dengan menggunakan metode Miles and Hubermen. Adapun informan dalam penelitian ini berjumlah lima orang yang terdiri dari Kepala Bidang Pelayanan Kesehatan Dinas Kesehatan Provinsi Jambi, Kepala Bidang Pemberdayaan Rehabilitasi Sosial Dinas Sosial Kabupaten Batang Hari, Kepala Seksi Komunitas Adat Terpencil Dinas Sosial, Kependudukan dan Pencatatan Sipil Provinsi Jambi, Pimpinan Fungsional PB (Pamong Belajar) BP - PAUD DIKMAS Jambi Kemdikbud Muara Bulian dan Manajer Program Sumatera Sustainable Support (SSS Pundi Sumatera). 


\section{HASIL DAN PEMBAHASAN}

Provinsi Jambi merupakan daerah yang memiliki populasi Komunitas Adat Terpencil SAD cukup banyak. Komunitas Adat Terpencil SAD ini ada yang telah diberdayakan (purnabina) dan hidup menetap. Namun ada pula yang masih berpindah-pindah tempat (nomaden) yang sebagian besar tinggal di kawasan hutan, terutama dalam kawasan Cagar Alam atau Taman Nasional. Batang Hari merupakan salah satu Kabupaten di Provinsi Jambi yang terdapat Komunitas Adat Terpencil SAD. Komunitas Adat Terpencil SAD ini memiliki permasalahan sosial yang kompleks seperti kemiskinan, pendidikan, dan kesehatan.

Diketahui bahwa Pemerintah Provinsi Jambi melalui SK Gubernur Jambi No. 860 Tahun 2014 tentang Penetapan Kelompok Kerja Komunitas Adat Terpencil Provinsi Jambi Tahun 2014 telah mengeluarkan kebijakan yang menjadi acuan dalam pelaksanaan program pemberdayaan Komunitas Adat Terpencil SAD di Provinsi Jambi. Selain itu Pemerintah Kabupaten yang dalam hal ini merupakan Kabupaten Batang Hari melalui SK Bupati Batang Hari Tahun 2018 tentang Pembentukan Kelompok Kerja Komunitas Adat Terpencil Kabupaten Batang Hari Periode 2018 - 2020 sebagai acuan dalam pelaksanaan program pemberdayaan Komunitas Adat Terpencil SAD di Kabupaten Batang Hari. Dalam melaksanakan pemberdayaan Komunitas Adat Terpencil SAD, Pemerintah bersama OPD melakukan kegiatan sesuai dengan bidang masing-masing.

Adapun kegiatan-kegiatan yang dilakukan oleh Pemerintah Provinsi maupun Kabupaten Batang Hari dapat dilihat pada tabel dibawah ini:

Tabel 1. Distribusi Jenis Kegiatan OPD dalam Pemberdayaan Komunitas Adat Terpencil SAD di Provinsi Jambi

\begin{tabular}{lll}
\hline No. & \multicolumn{1}{c}{ Kegiatan OPD dalam } \\
Mendukung Kegiatan Daerah & Keterangan \\
\hline 1. & Pelayanan Kesehatan Langsung & Berkelanjutan \\
\hline 2. & Pengecekan Status Kesehatan & Berkelanjutan \\
\hline 3. & Penyuluhan Kesehatan & Berkelanjutan \\
\hline 4. & Pembentukan Kader-kader & Tidak berkelanjutan \\
\hline 5. & Pendampingan akses ke RSUD & Tidak berkelanjutan \\
\hline 6. & Pembangunan Pemukiman & Tidak Berkelanjutan \\
\hline 7. & Pemberian Bantuan Sosial & Berkelanjutan \\
\hline 8. & Pemberian Bantuan Ternak & Tidak Berkelanjutan \\
\hline 9. & Pendataan Warga & Tidak Berkelanjutan \\
\hline
\end{tabular}

Berdasarkan data diatas diketahui bahwa kegiatan OPD dalam mendukung kegiatan daerah telah cukup banyak dilakukan. Kegiatan tersebut merupakan program dalam bidang kesehatan dan sosial. Dari semua kegiatan yang dilakukan terdapat kegiatan yang dilakukan secara berkelanjutan atau rutin dilaksanakan setiap bulannya dan ada pula yang tidak berkelanjutan. Kegiatan-kegiatan tersebut diantaranya: 1) pelayanan kesehatan langsung, 2) pengecekan status kesehatan, 3) penyuluhan kesehatan, 4) pembentukan kader-kader, 5) pendampingan ke RSUD Raden Mattaher, 6) pembangunan pemukiman, 7) pemberian bantuan sosial, 8) pemberian bantuan ternak dan 9) pendataan warga.

Hasil penelitian menunjukkan kebijakan yang dikeluarkan oleh Pemerintah beserta perangkatnya telah berperan dalam upaya pemberdayaan masyarakat. Hal ini seperti dapat merangsang, mendorong, atau memotivasi setiap individu agar mempunyai kemampuan atau keberdayaan untuk menentukan apa yang menjadi pilihan hidupnya. Akan tetapi pada kenyataannya, upaya pemerintah daerah selama ini dalam melakukan pemberdayaan masyarakat tidaklah mudah.

Hal ini dibuktikan dengan keadaan dan kondisi di lapangan, dimana perilaku birokrasi lokal masih kurang mendukung, komitmen yang rendah dari aparatur pelaksana, tingkat pendidikan masyarakat rendah dan partisipasi masyarakat yang rendah, masalah struktur sosial yang menghambat, keterisolasian masyarakat, 
adanya norma masyarakat yang bersifat negatif serta persepsi keliru yang telah terbentuk di masyarakat merupakan permasalahan umum yang dihadapi pemerintah dalam memberdayakan Komunitas Adat Terpencil SAD.

Program pemberdayaan Komunitas Adat Terpencil SAD yang dilakukan melibatkan beberapa unsur dinas terkait yang ikut memberdayakan Komunitas Adat Terpencil SAD, yang terdiri dari: Dinas Sosial, Kependudukan dan Pencatatan Sipil Provinsi Jambi, Universitas Jambi, Badan Perencanaan Pembangunan Daerah Jambi, BPN Jambi dan Dinas Kehutanan Provinsi Jambi.

\section{Pemberdayaan Komunitas Adat Terpencil di Bidang Kesehatan}

Hasil penelitian menunjukkan Pemerintah telah berupaya dalam melakukan pemberdayaan di bidang kesehatan dengan memberikan pelayanan kesehatan bagi Komunitas Adat Terpencil SAD sebagai bentuk upaya dalam memberdayakan Komunitas Adat Terpencil SAD dan meningkatkan derajat kesehatan mereka. Kabupaten Tebo dan Muaro Bungo telah menyiapkan program Puskesmas Keliling yang dilaksanakan setiap bulannya. Bentuk kegiatannya pun beragam mulai dari pengobatan, penyuluhan kesehatan dan Posyandu bagi balita. Program pelayanan kesehatan langsung ini dipandu oleh Dinas Kesehatan Provinsi Jambi dan dilaksanakan di tiap-tiap Kabupaten yang terdapat Komunitas Adat Terpencil SAD. Selain itu Komunitas Adat Terpencil SAD dapat mengakses layanan kesehatan di RSUD Raden Mattaher yang dibantu oleh tenaga kesehatan setempat. Pada kondisi Komunitas Adat Terpencil SAD, ketika mereka ingin berobat ke RSUD masih membutuhkan pendampingan dari fasilitator. Hal ini disebabkan karena Komunitas Adat Terpencil SAD tidak memahami prosedur yang harus dilakukan guna mendapatkan pelayanan kesehatan di faskes.

Hasil penelitian menunjukkan pelayanan kesehatan yang telah diberikan oleh tenaga kesehatan terhadap Komunitas Adat Terpencil SAD belum meningkatkan derajat kesehatan Komunitas Adat Terpencil SAD tersebut. Selain itu, Upaya yang telah dilakukan oleh Pemerintah termasuk dalam realisasi layanan kesehatan bagi Komunitas Adat Terpencil SAD belum sepenuhnya dikatakan berhasil. Hal ini dikarenakan Komunitas Adat Terpencil SAD masih menganut budaya primitif dan mempercayai hal-hal ghaib seperti jampi-jampi. Namun sebagaimana telah dipersiapkan dan dilakukan berbagai upaya dalam rangka meningkatkan derajat kesehatan Komunitas Adat Terpencil SAD ini, dalam realitanya pelayanan kesehatan yang dilakukan terhadap Komunitas Adat Terpencil SAD belum sepenuhnya diterima oleh kelompok ini. Hal ini dapat dilihat dengan proses persalinan masih dilakukan oleh dukun beranak dari kelompok ini dan mereka tidak mempercayakan proses persalinan tersebut ditangani oleh bidan maupun dokter.

Penelitian yang dilakukan oleh Octavianus Katuhu (2014) menunjukkan bahwa keberhasilan dari sebuah program dipengaruhi secara langsung oleh tingkat partisipasi masyarakat di dalam ruang lingkup itu sendiri. Jika tingkat partisipasi masyarakat itu tinggi maka dapat dipastikan tingkat keberhasilan program tersebut akan tinggi pula, begitu pula sebaliknya. Dimana program yang dilakukan bertujuan untuk memberikan bayangan atau menciptakan masyarakat-masyarakat yang berkompeten dan berguna bagi keberlanjutan dari program pemberdayaan ${ }^{5}$.

Penelitian yang dilakukan oleh Mulyadi (2013) menunjukkan bahwa pada program pemberdayaan, masyarakat adat hanya terlibat dalam tahap pelaksanaan sehingga masyarakat terbiasa menunggu program yang dirumuskan 
oleh pemerintah namun tidak dilibatkan ketika merumuskan apa yang menjadi kebutuhan dan harapan masyarakat adat tersebut ${ }^{6}$.

Hal ini sesuai dengan hasil penelitian, dimana Komunitas Adat Terpencil SAD yang memiliki pola kehidupan yang masih primitif sehingga beberapa program kesehatan belum mampu diterima karena dianggap tidak sesuai dengan norma dan kultur budaya mereka. Selain itu, Komunitas Adat Terpencil SAD masih mempercayai jampi-jampi dan pengobatan tradisional lainnya. Komunitas Adat Terpencil SAD juga terbiasa menerima bantuan dari pemerintah termasuk dalam hal kesehatan. Namun seiring berjalannya waktu, Komunitas Adat Terpencil SAD yang telah digarap dan diberdayakan oleh pemerintah kini mulai beralih ke pelayanan kesehatan yang dilakukan oleh petugas kesehatan yang kompeten. Namun sebagian besar proses persalinan dari Komunitas Adat Terpencil SAD masih dilakukan oleh dukun beranak yang berasal dari komunitas ini sendiri. Untuk itu pemerintah mulai melakukan upaya-upaya dalam bidang kesehatan khususnya proses persalinan. Disisi lain, kelompok masyarakat setempat mendukung kegiatan pelayanan kesehatan yang diberikan kepada Komunitas Adat Terpencil SAD. Hal ini dibuktikan dengan adanya kader-kader dan dukun beranak yang mengikuti pelatihan bersama bidan terkait penanganan persalinan yang lebih baik.

Berdasarkan hasil penelitian diketahui bahwa faktor pendorong dalam pelaksanaan kegiatan pelayanan kesehatan yang diberikan kepada Komunitas Adat Terpencil SAD adalah peran serta dari lining sectoral dan dukungan dari Pemerintah Daerah maupun Provinsi terkait hal-hal yang dapat membantu petugas kesehatan dalam memberikan pelayanan kesehatan yang optimal kepada Komunitas Adat Terpencil $\mathrm{SAD}$, seperti penerapan kegiatan berobat gratis yang telah dilaksanakan dibeberapa Kabupaten agar dapat dilaksanakan diseluruh Kabupaten di wilayah tempat tinggal Komunitas Adat Terpencil SAD.

Dalam hal ini diperlukan iklim politik yang mendukung kesehatan bagi semua, kerjasama antar OPD, alokasi sumber daya dan pembiayaan, penyebaran pendapatan yang merata, angka melek huruf dan tingkat pendidikan yang baik, ketersediaan sarana kesehatan, pengendalian pertumbuhan penduduk, jaminan kesehatan serta kebijakan yang berkesinambungan yang mengarah pada tingkat progres yang positif.

Secara sederhana sangat diperlukan sikap gotong royong dan kerjasama lintas sektoral dalam upaya memberikan pelayanan kesehatan yang optimal bagi seluruh masyarakat, tidak terkecuali Komunitas Adat Terpencil SAD. Selain itu penting untuk dilakukan upaya guna memaksimalkan faktor pendorong dalam pelaksanaan kegiatan pelayanan kesehatan diberikan kepada Komunitas Adat Terpencil SAD yaitu dengan melibatkan lining sectoral dan advokasi kebijakan.

Hal ini dapat dilihat dalam konteks pembiayaan program, bantuan dari pemerintah merupakan suatu upaya pembiayaan masyarakat, atau merupakan suatu upaya yang dilakukan pemerintah dalam memberikan daya (baik itu sumber daya/modal, peluang, pengetahuan, dan keahlian) kepada masyarakat sehingga dapat meningkatkan kemampuan, kapasitas, dan rasa percaya diri mereka, agar mampu mengatasi masalah kemiskinan yang sedang dihadapi dalam rangka mencapai kehidupan yang lebih baik.

Dalam hal ini pemerintah terutama Dinas Kesehatan dan Puskesmas memiliki tanggung jawab untuk menggalang kerja sama lintas sektoral, melakukan penganggaran pada program pemberdayaan Komunitas Adat Terpencil SAD, melaksanakan perencanaan serta pendekatan dan bina suasana antar instansi dan lembaga yang ada, melakukan pemberdayaan terhadap masyarakat, 
melaksanakan survey mawas diri dan musyawarah serta mendorong mereka agar menanggapi positif setiap program kesehatan yang telah diprioritaskan bersama. Memberikan ruang bagi masyarakat untuk menilai dan mengevaluasi kegiatan program kesehatan sebagai salah satu bentuk menempatkan meraka bukan hanya sebagai objek dalam pelaksanaan bidang kesehatan.

Disisi lain petugas kesehatan/kader/LSM kerap menjumpai hambatan dalam memberikan pelayanan kesehatan terhadap Komunitas Adat Terpencil SAD, yaitu keterbatasan dana, SDM dan waktu. Hal lain yang juga menjadi hambatan adalah pola kehidupan Komunitas Adat Terpencil SAD yang berpindah-pindah (nomaden) sehingga petugas cukup kesulitan dalam memberikan pelayanan kesehatan terhadap kelompok ini. Selain itu, belum ada kesinambungan antara Dinas Kesehatan Provinsi Jambi dengan Dinas Kesehatan Kabupaten terkait pelayanan kesehatan yang diberikan karena seperti diketahui dalam wawancara tersebut bahwa Dinas Kesehatan Provinsi Jambi dan Dinas Kesehatan Kabupaten turun ke lapangan (lokasi Komunitas Adat Terpencil SAD) tidak bersama-sama atau tidak dalam rentan waktu yang sama.

Perlu langkah yang terencana, sosialisasi dan promosi kesehatan serta peningkatan kinerja hubungan dengan masyarakat terutama memasyarakatkan visi dan misi, tujuan serta strategi dan arah kebijakan pembangunan kesehatan, sehingga pemerintah beserta masyarakatnya memiliki rasa tanggungjawab terhadap masalah kesehatan dirinya, keluarga dan lingkungannya. Selanjutnya, memanfaatkan semaksimal mungkin keterlibatan kelompok masyarakat tertentu (pemangku kebijakan, pemerhati kesehatan, donatur, politisi), Lembaga Swadaya Masyarakat (LSM) secara bersama-sama membangun landasan pola pikir untuk menata kehidupan masyarakat yang sehat. Selain itu diperlukan upaya yang lebih serius dari Pemerintah Provinsi Jambi maupun Kabupaten terutama dalam pengalokasian dana yang dapat membantu dalam program pemberdayaan Komunitas Adat Terpencil SAD.

\section{Pemberdayaan Komunitas Adat Terpencil SAD di Bidang Sosial}

Dalam upaya pengoptimalan pelaksanaan kegiatan pemberdayaan Komunitas Adat Terpencil SAD dibutuhkan kesungguhan dari pemerintah maupun masyarakat menjadi hal penting untuk dapat membantu dalam proses memandirikan Komunitas Adat Terpencil SAD. Selain itu terjalinnya komunikasi yang baik dan melibatkan Komunitas Adat Terpencil SAD secara partisipatif dalam pelaksanaan kegiatan pemberdayaan kesehatan dapat dijadikan solusi untuk meminimalisir kegagalan program pemberdayaan.

Dalam hal ini guna mengawal kebijakan dapat dilakukan dengan melakukan musrenbang yang melibatkan masyarakat guna mengatasi permasalahan yang dihadapi oleh Komunitas Adat Terpencil SAD. Dimana masyarakat bisa secara aktif mempengaruhi rencana anggaran kota dan bentuk program-program yang sedang disusun. Melalui musrenbang, Masyarakat di tingkat lokal dan pemerintah punya tanggungjawab yang sama dalam membangun wilayahnya. Masyarakat seharusnya berpartisipasi karena ini merupakan kesempatan untuk secara bersama menentukan masa depan wilayah. Masyarakat juga harus memastikan pembangunan yang dilakukan pemerintah sesuai dengan kebutuhan.

Fakta dilapangan menunjukkan bahwa Pemerintah telah memberikan perhatian kepada kelompok SAD dalam aspek pembangunan berkelanjutan. Pemerintah berusaha untuk meningkatkan dan memperbaiki kehidupan sosio-ekonomi masyarakat itu. Salah satu aspek utamanya adalah meningkatkan tahap kesejahteraan mereka dengan cara menyediakan pemukiman, memberikan pendidikan kepada 
masyarakat, memberikan layanan kesehatan, membangun sistem ekonomi, dan sebagainya.

Hasil penelitian menunjukkan bahwa Pemerintah telah berupaya dalam memberdayakan Komunitas Adat Terpencil SAD. Namun dalam penerapannya kebijakan yang sudah pemerintah keluarkan belum menunjukkan hasil yang signifikan dikarenakan Komunitas Adat Terpencil SAD membutuhkan waktu sedikit lebih lama agar dapat menyesuaikan dengan harapan Pemerintah. Selain itu, kesungguhan dari Pemerintah maupun masyarakat menjadi point penting untuk dapat membantu dalam proses memandirikan Komunitas Adat Terpencil SAD.

Hasil penelitian menunjukkan Komunitas Adat Terpencil SAD memiliki norma dan budaya yang berbeda dengan masyarakat pada umumnya, sehingga mereka kesulitan dalam menyesuaikan diri dengan keadaan disekitarnya. Faktor-faktor lain yang menghambat pemberdayaan pada Komunitas Adat Terpencil SAD ini adalah masalah struktural yang telah mengalahkan masyarakat adat terhadap keinginanan pribadi aparat desa atau lapisan yang lebih kuat. Selain itu, mekanisme pengawasan, monitoring dan evaluasi, serta koordinasi antar lembaga yang belum berjalan sebagaimana mestinya.

Dalam memberdayakan Komunitas Adat Terpencil SAD, Pemerintah sering mendapati kendala di lapangan maupun dalam tahap perencanaan. Faktor internal dan faktor eksternal sangat mempengaruhi pengembangan sumber daya manusia yang dalam hal ini merupakan Komunitas Adat Terpencil SAD. Faktor internal mencakup keseluruhan kehidupan yang dapat dikendalikan baik oleh pemimpin maupun oleh anggota dalam kelompok masyarakat yang bersangkutan, seperti: kebiasaan, ketergantungan dan rasa tidak percaya diri. Sedangkan faktor-faktor eksternal yang mempengaruhi kelompok masyarakat tersebut antara lain: kebijakan pemerintah, sosio-budaya masyarakat dan perkembangan ilmu pengetahuan dan teknologi yang belum mampu diikuti oleh Komunitas Adat Terpencil SAD.

Berdasarkan hasil penelitian diketahui hambatan-hambatan dalam pelaksanaan program pemberdayaan Komunitas Adat Terpencil SAD di bidang sosial menyebabkan realisasi program tidak optimal.

Adapun hambatan-hambatan tersebut diantaranya:

1) Komunitas Adat Terpencil SAD yang masih berpindah-pindah (nomaden) sehingga menyulitkan petugas dalam melaksanakan program pemberdayaan.

2) Jangkauan ke wilayah Komunitas Adat Terpencil SAD yang terbilang jauh.

3) Jumlah warga Komunitas Adat Terpencil SAD yang tidak upgrade.

4) Ketentuan Permendagri No. 14 Tahun 2016yang mengharuskan warga memiliki buku nikah (sudah menikah) baru bisa membuat KK (Kartu Keluarga), sementara Komunitas Adat Terpencil SAD tidak memahami hal-hal yang demikian.

5) Sebagian besar dari Komunitas Adat Terpencil SAD tidak memiliki kartu identitas (KTP) dan petugas juga kesulitan dalam melakukan perekaman data untuk pembuatan KTP dikarenakan Komunitas Adat Terpencil SAD yang masih berpindah-pindah (nomaden).

6) Lintas sektoral tidak optimal dalam menjalankan program pemberdayaan KAT di bidang sosial.

7) Tidak ada anggaran khusus bagi Komunitas Adat Terpencil SAD baik dari APBD maupun APBN.

Pemerintah Provinsi Jambi maupun Kabupaten memiliki tujuan yang sama dalam pelaksanaan program pemberdayaan Komunitas Adat Terpencil SAD di bidang sosial. Pemerintah ingin Komunitas Adat Terpencil 
SAD memiliki kondisi lingkungan yang mendukung mereka dalam mengembangkan kemampuan adaptasi terhadap perubahan lingkungan sosial, budaya, ekonomi, politik dan ideology. Dalam mencapai tujuan dari pelaksanaan program pemberdayaan Komunitas Adat Terpencil SAD di bidang sosial, hendaknya melibatkan seluruh elemen masyarakat sehingga masyarakat memiliki peran dan tanggungjawab yang sama dan dapat berpartisipasi dalam kehidupan bermasyarakat secara bersama-sama.

Strategi implementasi pemberdayaan masyarakat membutuhkan langkah nyata agar berhasil memenuhi sasaran dan tujuannya. Implementasi kebijakan dan program pemberdayaan masyarakat perlu dimantapkan dan dilanjutkan. Selain itu, pelaksanaan kegiatanya perlu ditempatkan pada arah yang benar, yaitu ditujukan pada peningkatan kapasitas masyarakat (capacity, building) yang berfokus pada pemberian akses dan peningkatan ekonomi rakyat melalui pengembangan ekonomi, memperkuat kapasitas sumberdaya manusia, mengembangkan prasarana/sarana (infra-structure) dan teknologi ${ }^{7}$.

Jika dikaitkan dengan upaya yang telah Pemerintah Provinsi Jambi maupun Kabupaten lakukan terhadap pelaksanaan program pemberdayaan Komunitas Adat Terpencil SAD di bidang sosial kita dapat memahami keterkaitan antara satu dengan yang lain. Upaya yang telah Pemerintah Provinsi Jambi lakukan dipelopori oleh Dinas Sosial, Kependudukan dan Pencatatan Sipil Provinsi Jambi melakukan lining sectoral dengan Instansi Pemeintah lainnya, diantaranya: Dinas Kehutanan Provinsi Jambi; BAPPEDA Provinsi Jambi; BPN Jambi, LSM (seperti Pundi Sumatera); dan Perguruan Tinggi (Universitas Jambi).

Sedangkan Pemerintah Kabupaten Batang Hari juga melakukan lining sectoral dengan OPD (Organisasi Perangkat Daerah). Upaya lain yang telah Pemerintah lakukan diantaranya melakukan pendekatan dengan Tumenggung (Kepala SAD), melakukan penjajakan awal, melakukan sosialisai, memberikan motivasi dan pemberian jaminan hidup berupa pemukiman. Pemerintah juga membantu Komunitas Adat Terpencil SAD dalam pembuatan kartu identitas (KTP).

Pemerintah memiliki peranan penting dalam pelaksanaan program pemberdayaan Komunitas Adat Terpencil SAD. Untuk dapat merealisasikan apa yang diharapkan seharusnya Pemerintah bisa melakukan berbagai upaya secara sistematis, terencana dan bersinergi dengan seluruh elemen masyarakat dalam rangka meningkatkan derajat kesejahteraan rakyat, yang dalam hal ini merupakan Komunitas Adat Terpencil SAD.

Upaya menyeluruh hingga tingkat daerah perlu dilakukan untuk menjaga konsistensi dan efektivitas keberhasilan program. Perhatian pemerintah dalam pelaksanaan program pemberdayaan Komunitas Adat Terpencil SAD cukup besar. Begitu banyak program yang telah dilaksanakan untuk mengatasi permasalahan yang ada, hal ini dapat dilihat dari berbagai program yang telah berjalan.

Pemerintah Provinsi Jambi dengan Pemerintah Kabupaten yang dalam hal ini Kabupaten Batang Hari, memiliki perbedaan dalam merealisasikan program. Hal ini dapat dilihat dari hasil wawancara dengan informan diketahui bahwa peranan Pemerintah Provinsi Jambi dengan Pemerintah Kabupaten Batang Hari terdapat perbedaan persepsi. Diantaranya Pemerintah Provinsi Jambi menyiapkan pemukiman bagi Komunitas Adat Terpencil SAD, namun Komunitas Adat Terpencil SAD ini memilih kembali tinggal di sudung. Sedangkan Pemerintah Kabupaten Batang Hari sejak awal menyiapkan sudung bagi Komunitas Adat Terpencil SAD dikarenakan status kepemilikan tanah yang harus jelas. Selain itu Pemerintah Kabupaten juga memberikan bantuan bahan pokok bagi Komunitas Adat 
Terpencil SAD, namun hal ini dilakukan tidak berkelanjutan.

\section{Keberlanjutan Program Pemberdayaan Komunitas Adat Terpencil SAD}

Dalam pelaksanaan pemberdayaan Komunitas Adat Terpencil SAD, Pemerintah bersama NGO/LSM dan masyarakat bersama melakukan upaya dalam memandirikan masyarakat Komunitas Adat Terpencil SAD dan mengeluarkan mereka dari keterangisan dan bersama-sama dalam pembangunan berkelanjutan. NGO diketahui memiliki peranan yang penting dan telah membantu pemerintah dalam memandirikan masyarakat Komunitas Adat Terpencil SAD.

Pada tahun 2011 NGO Pundi Sumatera mulai masuk ke wilayah SAD yang dimulai dengan penjajakan awal, melakukan penelitian dan melakukan survey dengan membuat assessment. Tujuan dari pembuatan assessment ini adalah mendapati kesepakatan antara NGO dengan SAD dalam hal pendampingan pemberdayaan. Diantaranya Komunitas Adat Terpencil SAD yang bersedia untuk didampingi dalam hal pemberdayaan Komunitas Adat Terpencil SAD ini, terdapat pula Komunitas Adat Terpencil SAD yang menolak atau tidak bersedia didampingi. Hal ini didasari Komunitas Adat Terpencil SAD ini telah krisis kepercayaan terhadap NGO ataupun orang-orang diluar kelompoknya karena sebelumnya memberikan kesan yang kurang baik terhadap kelompok ini seperti janji-janji dalam memberikan sesuatu namun tidak terlaksana sehingga kelompok ini enggan untuk menerima kembali bantuan ataupun pendampingan.

Pada tahun 2012, kegiatan pendampingan pemberdayaan mulai efektif dilakukan. NGO Pundi Sumatera berfokus pada Komunitas Adat Terpencil SAD yang berada di jalur tengah lintas sumatera, dimana Komunitas Adat Terpencil SAD ini sudah lama keluar dari kawasan hutan. Adapun kegiatan pendampingan yang dilakukan yaitu: 1) Fasilitas dokumen kependudukan, 2) Layanan pendidikan, 3) Layanan kesehatan yang bekerja sama dengan Puskesmas, Rumah Sakit dan Dinas Kesehatan Kabupaten dan 4) Pengembangan sumber daya ekonomi kreatif.

Hasil penelitian menunjukkan bahwa NGO Pundi Sumatera telah membantu dalam berbagai upaya memandirikan masyarakat dan bersama pemerintah melakukan upaya - upaya nyata. Hal ini perlu terus ditingkatkan terutama oleh pemerintah yang memiliki tugas dan tanggungjawab terhadap masyarakatnya. NGO Pundi Sumatera memiliki harapan ketika mereka keluar atau berhenti melakukan pendampingan terhadap Komunitas Adat Terpencil SAD, Pemerintah dalam melanjutkan berbagai program pemberdayaan Komunitas Adat Terpencil SAD yang telah dilakukan secara optimal dalam segala aspek, termasuk dari SDM dan penganggaran khusus bagi Komunitas Adat Terpencil SAD dari APBD maupun APBN.

\section{KESIMPULAN DAN SARAN}

Kesimpulan yang didapat dalam penelitian ini yaitu: 1) Kebijakan pemerintah melalui SK Gubernur Jambi dan SK Bupati Batang Hari belum terlaksana dengan baik oleh anggota pokja KAT dikarenakan anggaran tidak tersedia 2) Pemberdayaan Komunitas Adat Terpencil SAD di bidang kesehatan yang telah dilakukan oleh Pemerintah berupa pelayanan kesehatan langsung ke lokasi Komunitas Adat Terpencil $\mathrm{SAD}$, pengecekan kesehatan, pengobatan gratis, akses layanan ke RSUD Raden Mattaher dan pembentukan kader yang membantu dalam proses persalinan pada Komunitas Adat Terpencil SAD. Sedangkan pemberdayaan Komunitas Adat Terpencil SAD di bidang sosial telah dilakukan Pemerintah dengan menyediakan pemukiman bagi Komunitas Adat Terpencil SAD, memberikan bantuan berupa makanan pokok dan ternak, membantu 
Komunitas Adat Terpencil SAD dalam pendataan diri maupun keluarga dan membantu dalam proses pemandirian Komunitas Adat Terpencil SAD. Namun upaya yang telah Pemerintah lakukan belum terealisasikan dengan baik. Hal ini disebabkan Komunitas Adat Terpencil SAD masih belum mampu memberdayakan dirinya maupun keluarganya secara mandiri. Komunitas Adat Terpencil SAD hanya menerima bantuan dari Pemerintah tetapi belum dapat mengembangkan bantuan tersebut, 3) NGO berperan dalam memberdayakan Komunitas Adat Terpencil SAD dengan turun langsung dan membantu mengatasi permasalahan Komunitas Adat Terpencil SAD dalam bidang kesehatan maupun sosial. Selain itu, NGO menggandeng pemerintah dalam melaksanakan kegiatan pemberdayaan seperti pendataan, pemberian bantuan sosial, pemberian ternak dan pelatihan kader-kader kesehatan. Upaya yang telah dilakukan dalam memandirikan Komunitas Adat Terpencil SAD berupa training, Hal ini dilakukan guna ketika NGO pergi dari lingkungan Komunitas Adat Terpencil SAD, Pemerintah dapat melanjutkan berbagai upaya yang telah NGO lakukan dan dapat melakukan penganggaran yang optimal baik dari APBD maupun APBN dalam pelaksanaan program pemberdayaan Komunitas Adat Terpencil SAD.

Adapun saran yang dapat diberikan yaitu: 1) Pemerintah diharapkan dapat menyiapkan anggaran setiap tahunnya baik dari ABPD maupun APBN dalam pelaksanaan program pemberdayaan Komunitas Adat Terpencil SAD di Provinsi Jambi, 2) OPD diharapkan dapat mengoptimalkan kinerja dan meningkatkan sinergitas antar lintas sektoral, 3) Masyarakat diharapkan dapat ikut serta dalam pelaksanaan program pemberdayaan Komunitas Adat Terpencil SAD sehingga masyarakat mempunyai rasa tanggungjawab yang tinggi terhadap program tersebut.

\section{DAFTAR PUSTAKA:}

1. Koentjaraningrat, 2009. Pengantar Ilmu Antropologi. Edisi revisi. Jakarta: Rineka Cipta.

2. Dinsosdukcapil Provinsi Jambi. 2017. Data Komunitas Adat Terpencil di Provinsi Jambi berdasarkan Hasil Pemutahiran Data Kemensos RI.

3. Dinsosdukcapil Provinsi Jambi. 2017a. Data sebaran warga komunitas adat terpencil di Provinsi Jambi berdasarkan yang sudah diberdayakan sampai tahun 2017.

4. Creswell John.W. 2014. Penelitian Kualitatif \& Desain Riset. Yogyakarta: Pustaka Pelajar.

5. Octavianus Katuhu. 2015. Evaluasi Kebijakan Program Nasional Pemberdayaan Masyarakat Mandiri Pedesaan (PNPM-MD) di Kecamatan Siau Timur.

6. Mulyadi, M., 2013. Pemberdayaan Masyarakat Adat dalam Pembangunan Kehutanan. Jurnal Penelitian Sosial dan Ekonomi Kehutanan, 10 (4).

7. Sumodiningrat, $G$ \& Wulandari A., 2015. Menuju Ekonomi Berdikari. Cetakan ke-1. Yogyakarta: Media Pressindo.

8. Patton, Q.M., 2009. Metode Evaluasi Kualitatif. Cetakan ke-2. Yogyakarta: Pustaka Pelajar. 